\title{
Kemampuan Motorik Halus Anak Usia 4-5 Tahun Melalui Model Pembelajaran Sentra Alam Di PAUD (Kober) Bintang Kecil Kecamatan Karawaci Kota Tangerang
}

\author{
${ }^{1}$ Dewi Yuliana, ${ }^{2}$ Saipul Bahri \\ Program Studi Pendidikan Guru Pendidikan Anak Usia Dini; Fakultas Keguruan \\ Dan Ilmu Pendidikan; Universitas Muhammadiyah Tangerang \\ Email : ${ }^{1}$ yuldewi@gmail.com, ${ }^{2}$ bahrisaipul@rocketmail.com
}

\begin{abstract}
Abstrak
Pendidikan untuk anak usia dini (0-8 tahun) merupakan pendidikan yang memiliki karakteristik berbeda dengan anak usia lain, sehingga pendidikannyapun perlu dipandang sebagai sesuatu yang dikhususkan. Salah satu metode yang dapat digunakan pendidik untuk meningkatkan kemampuan motorik halus anak tersebut adalah dengan model pembelajaran sentra alam. Kurangnya kemampuan motorik halus anak menjadi masalah yang dihadapi guru kelompok A di PAUD ( KOBER ) Bintang Kecil Kecamatan Karawaci Kota Tangerang. Metode yang digunakan adalah metode Penelitian Tindakan Kelas (PTK). Hal ini dibuktikan dengan adanya peningkatan sebesar 10\% dari kondisi awal ke siklus I yakni dari $10 \%$ menjadi $20 \%$. Sikus II mengalami peningkatan sebesar $60 \%$ dari kondisi awal dan peningkatan sebesar $40 \%$ dari siklus II yaitu diperoleh hasil sebesar $80 \%$. Sehingga dapat disimpulkan bahwa model pembelajaran sentra alam dapat meningkatkan kemampuan motorik halus anak usia 4-5 tahun PAUD (KOBER) Bintang Kecil Kecamatan Karawaci, Kota Tangerang. Berdasarkan hasil penelitian ini menunjukkan bahwa dengan model pembelajaran sentra alam dapat dikatakan berhasil dalam rangka meningkatkan kemampuan motorik halus anak usia 4-5 tahun, untuk itu disarankan pada semua guru dapat memberikan kegiatan bermain sentra alam yang menarik dan menyenangkan, guru juga harus mampu menciptakan lingkungan pembelajaran yang nyaman dan menyenangkan anak.

KATA KUNCI : Kemampuan Motorik Halus, Model Pembelajaran, Sentra Alam
\end{abstract}

\section{Pengantar}

Pendidikan anak usia dini merupakan pendidikan yang sangat mendasar dan strategis dalam pengembangan sumber daya manusia yang berpotensi. Dalam undang-undang RI No.20 tahun 2003 pasal 28 ayat 3 bahwa pendidikan anak usia dini pada jalur pendidikan formal yang bertujuan Bmembantu anak 


\section{"Ceria"}

Jurnal Pendidikan Anak Usia Dini

ISSN 2301-9905

Volume 10, No. 1, Juli 2019

Fakultas Keguruan dan Ilmu Pendidikan- Universitas Muhammadiyah Tangerang

didik mengembangkan berbagai potensi baik psikis dan fisik yang meliputi moral dan nilai agama, sosial, emosional, kemandirian, kognitif, bahasa, fisik motorik dan seni untuk anak memiliki kesiapan dalam memasuki pendidikan lebih lanjut (Dirjen.PAUDNI: 2011).

Berpijak dari hal tersebut di atas, sejak tahun 2003 Pemerintah melalui Direktorat Pembinaan Pendidikan Anak Usia Dini, Kementrian Pendidikan dan Kebudayaan telah memberikan dukungan bagi lembaga atau organisasi masyarakat untuk mengembangkan berbagai program layanan Pendidikan Anak Usia Dini. Wujud dari dukungan tersebut adalah diberikanya berbagai macam bantuan sarana dan prasarana seperti media permainan out door dan alam. Pada dasarnya anak senang sekali belajar asal dilakukan dengan cara bermain yang menyenangkan. Maka dengan cara bermainlah para pendidik anak usia dini memberikan pembelajaran agar anak dapat menyerap semua konsep yang diberikan oleh pendidik dan sangat berguna untuk perkembangan pengetahuannya. Pendidikan Anak Usia Dini sangatlah penting, bahwa anak usia dini berada dalam masa usia keemasan dimana anak mulai peka untuk menerima berbagai stimulasi dan berbagai upaya pendidikan dari lingkungannya, baik disengaja maupun tidak disengaja. Di butuhkan situasi dan kondisi yang kondusif pada saat memberikan stimulasi dan upaya pendidikan yang sesuai dengan kebutuhan dan minat anak.

Kenyataan dilapangan menunjukan bahwa penyelenggaraan PAUD masih belum mengacu betul dengan tahap-tahap perkembangan anak (tidak sesuai dengan kurikulum). Pada umumnya penyelenggaraan difokuskan pada peningkatan kemampuan akademik baik dalam hal hafalan-hafalan maupun kemampuan baca tulis hitung, yang prosesnya sering kali mengabaikan tahapan perkembangan anak. Karena itu penting bagi guru untuk memprogram latihanlatihan motorik halus dalam pendidikan anak PAUD (Kelompok Bermain) 


\section{"Ceria"}

Jurnal Pendidikan Anak Usia Dini

ISSN 2301-9905

Volume 10, No. 1, Juli 2019

Fakultas Keguruan dan Ilmu Pendidikan- Universitas Muhammadiyah Tangerang

Bintang Kecil. Diperlukan suatu model pembelajaran yang membantu, mempermudah proses pembelajaran sehingga upaya mengoptimalkan kemampuan yang dimiliki anak dapat dikembangkan dan menumbuhkan motivasi belajar anak, semua itu harus dengan situasi belajar yang menyenangkan. Kemampuan motorik halus anak kurang dilatih secara intensif sehingga kemampuan motorik halus anak kurang optimal, pelatihan motorik anak sangat diperlukan untuk mengoptimalkan kemampuan motorik halus anak PAUD Bintang Kecil. Kemampuan motorik halus yang dimiliki anak rendah, anak kurang mampu menggunting, merobek kertas, meremas, menggambar, memegang benda dan menjepit,hal ini disebabkan latihan motorik halus anak yang kurang. Perkembangan motorik halus pada anak usia dini yaitu berupa gerakan - gerakan yang hanya melibatkan bagian - bagian tubuh tertentu saja dan dilakukan oleh otot - otot kecil, seperti gerakan mengambil sebuah benda dengan menggunakan ibu jari dan telunjuk tangan, menggunting, menyetir mobil, menulis, menjahit, menggambar, dan lain sebagainya, sehingga perkembangan motorik halus ini tidak terlalu membutuhkan tenaga, akan tetapi membutuhkan koordinasi yang cermat serta ketelitian dari anak tersebut.

Perkembangan kemampuan motorik diartikan sebagai perkembangan dari unsur kematangan dan pengendalian gerak tubuh. Keterampilan motorik halus baru mulai berkembang, yang diawali dengan kegiatan yang amat sederhana seperti memegang pensil, memegang sendok dan mangkuk (Woolfson, 2001, h. 127). Motorik halus lebih lama pencapaiannya dari pada keterampilan motorik kasar, karena keterampilan motorik halus membutuhkan kemampuan yang lebih sulit misalnya konsentrasi, control, kehati - hatian dan koordinasi otot tubuh yang satu dengan yang lain, (Woolfson, 2001, h.129).

Menurut Kartini Kartono, (1995, h.83 ) motorik halus adalah ketangkasan, keterampilan, jari tangan dan pergelangan tangan serta penugasan terhadap otot 


\section{"Ceria"}

Jurnal Pendidikan Anak Usia Dini

ISSN 2301-9905

Volume 10, No. 1, Juli 2019

Fakultas Keguruan dan Ilmu Pendidikan- Universitas Muhammadiyah Tangerang

- otot urat pada wajah. Pendapat lain yang dikemukakan oleh Astati, (1995, h.4 ) bahwa motorik halus adalah gerakan yang hanya menggunakan otot - otot tertentu saja dan dilakukan oleh otot - otot kecil yang membutuhkan koordinasi gerak dan daya konsentrasi yang baik.

Perkembangan kemampuan motorik diartikan sebagai perkembangan dari unsur kematangan dan pengendalian gerak tubuh. Keterampilan motorik halus baru mulai berkembang, yang diawali dengan kegiatan yang amat sederhana seperti memegang pensil, memegang sendok dan mangkuk (Woolfson, 2001, h. 127). Motorik halus lebih lama pencapaiannya dari pada keterampilan motorik kasar, karena keterampilan motorik halus membutuhkan kemampuan yang lebih sulit misalnya konsentrasi, control, kehati - hatian dan koordinasi otot tubuh yang satu dengan yang lain, (Woolfson, 2001, h.129).

Menurut Kartini Kartono, (1995, h.83 ) motorik halus adalah ketangkasan, keterampilan, jari tangan dan pergelangan tangan serta penugasan terhadap otot - otot urat pada wajah. Pendapat lain yang dikemukakan oleh Astati, (1995, h.4) bahwa motorik halus adalah gerakan yang hanya menggunakan otot - otot tertentu saja dan dilakukan oleh otot - otot kecil yang membutuhkan koordinasi gerak dan daya konsentrasi yang baik.

Sentra berasal dari kata " centre" yang artinya pusat. (Retno, 2010, h.14). Seluruh materi yang akan guru sampaikan kepada anak melalui kegiatan kegiatan yang sudah direncanakan perlu diorganisasikan secara teratur, sistematis, dan terarah sehingga anak dapat membangun kemampuan menganalisanya dan dapat mempunyai kemampuan mengambil kesimpulan. Sentra mengandung makna bahwa setiap kegiatan di semua sentra yang disediakan memiliki titik pusat (centre point), yang kesemuanya mengacu pada tujuan pembelajaran Retno, (2010, h.15). Pembelajaran sentra merupakan pembelajaran yang di fokuskan pada anak (student center) guru hanya sebagai 


\section{"Ceria"}

Jurnal Pendidikan Anak Usia Dini

ISSN 2301-9905

Volume 10, No. 1, Juli 2019

Fakultas Keguruan dan Ilmu Pendidikan- Universitas Muhammadiyah Tangerang

pengawas dan fasilitator, (Agustya, 2014, h.48). Sentra adalah suatu pendekatan pembelajaran yang berfokus pada anak yang dalam proses pembelajarannya berpusat di sentra bermain pada saat anak dalam lingkaran (circle time) (Ratna, 2014, h.41). Model pembelajaran berdasarkan sentra adalah pendidikan pembelajaran dalam proses pembelajaran dilakukan di dalam lingkaran dan sentra bermain dengan bahan alam.

\section{Metode}

Pendekatan yang akan dipilih bergantung pada masalah dan tujuan penelitian yang dilakukan. Penelitian ini bertujuan untuk meningkatkan kemampuan motorik halus melalui metode pembelajaran sentra alam. Dengan mengacu pada tujuan di atas, metode penelitian yang digunakan adalah pendekatan penelitian tindakan kelas melalui proses pengkajian dengan beberapa siklus.

Menurut Kemmis dan Mc.Taggart (Killen Roy, 1989, h.75) PTK adalah penelitian yang dilakukan oleh guru di dalam kelasnya sendiri melalui refleksi diri, dengan tujuan untuk memperbaiki kinerjanya sebagai guru, sehingga proses pembelajaran dapat berjalan dengan baik, dan hasilnya meningkat. Elliot (Sanjaya, 2006, h.53) melihat penelitian tindakan sebagai kajian dari sebuah situasi sosial dengan kemungkinan tindakan untuk memperbaiki kualitas sosial tersebut. PTK adalah penelitian yang merupakan suatu rangkaian langkahlangkah (a spiral of steps) setiap langkah terdiri atas 4 tahap yaitu perencanaan, tindakan, observasi, dan refleksi.

Dari banyak model PTK yang ada peneliti akan menggunakan model Kemmis \& Mc. Taggart. Cara kerja dari model Kemmis \& Mc.Taggart yaitu menggambarkan empat langkah dan pengulangan pada penelitiannya yaitu memakai siklus sebagai penelitiannya karena dalam satu siklus atau putaran 


\section{"Ceria"}

Jurnal Pendidikan Anak Usia Dini

ISSN 2301-9905

Volume 10, No. 1, Juli 2019

Fakultas Keguruan dan Ilmu Pendidikan- Universitas Muhammadiyah Tangerang

terdiri dari empat komponen yang meliputi Perencanaan (planning), tindakan (acting), observasi (observing), dan refleksi (reflecting), kemudian dilanjutkan dengan perencanaan ulang (replanning) tindakan, observasi serta refleksi untuk satu siklus selanjutnya.

\section{Hasil dan Pembahasan}

Hasil yang diperoleh dari data awal melalui lembar observasi mengenai kemampuan motorik halus pada anak usia 4-5 tahun, di PAUD (Kelompok Bermain) Bintang Kecil, Karawaci, menunjukkan bahwa kemampuan motorik halus anak pada usia 4-5 tahun kurang memuaskan, hal ini dapat diketahui dengan masih banyaknya siswa yang belum mampu menggambar sesuai dengan gagasannya, belum mampu meniru bentuk, belum mampu bereksplorasi dengan berbagai media dan kegiatan, belum mampu menggunakan alat tulis dengan benar, belum mampu menggunting sesuai dengan pola, serta belum mampu untuk menempel gambar dengan tepat. Berdasarkan hasil pengamatan yang dilakukan pada kondisi awal dari 10 orang anak di PAUD (Kelompok Bermain) Bintang Kecil yang telah Berkembang Sesuai Harapan ada 1 orang anak yaitu NZ, dan yang dalam tahap Berkembang ada 3 orang anak yaitu AW, AA dan NA. Dan yang Mulai Berkembang ada 4 orang yaitu AN, ANH, FAR, dan QF. Dan yang masih Belum Berkembang dalam perkembangan motorik halusnya ada 2 orang yaitu FBA, dan MNA. Sehingga perkembangan kemampuan motorik halus anak pada kondisi awal baru mencapai $10 \%$. Maka langkah selanjutnya yang akan dilakukan oleh peneliti agar kemampuan motorik halus anak dapat meningkat adalah dengan menggunakan metode pembelajaran sentra alam. Peneliti mencoba mencari jalan keluar masalah dengan upaya perbaikan pembelajaran dengan Penelitian Tindakan Kelas (PTK). Penelitian Tindakan Kelas yang dilakukan di PAUD (Kelompok Bermain) Bintang Kecil Karawaci ini 


\section{"Ceria"}

Jurnal Pendidikan Anak Usia Dini

ISSN 2301-9905

Volume 10, No. 1, Juli 2019

Fakultas Keguruan dan Ilmu Pendidikan- Universitas Muhammadiyah Tangerang

dilaksanakan dalam 3 siklus. Siklus I, II dan III, masing - masing dilaksanakan dalam 3 pertemuan.

Berasarkan hasil pengamatan yang dilakukan di Siklus I dari 10 anak di PAUD (Kelompok Bermain) Bintang Kecil yang telah Berkembang sesuai harapan ada 2 orang anak yaitu AA, dan NZ, dan yang dalam tahap Berkembang ada 4 orang anak yaitu AW, AN, NA dan QF. Dan yang Mulai Berkembang ada 4 orang yaitu ANH, FAR, FBA, dan MNA. Sehingga perkembangan kemampuan motorik halus anak yang terjadi pada siklus I ini mencapai $20 \%$ sehingga belum mencapai indikator keberhasilan dalam penelitian ini, maka perlu dilakukan siklus berikutnya yaitu siklus II.

Selanjutnya peneliti melakukan perbandingan perkembangan kemampuan motorik halus anak saat sebelum diberi tindakan (pra penelitian) dengan saat sesudah diberikan tindakan pada akhir siklus I. Hasil dari pengamatan tersebut memperlihatkan adanya peningkatan perkembangan motorik halus anak yang cenderung meningkat dan membaik pada siklus I. Dengan diterapkannya model pembelajaran sentra alam dalam pembelajaran.

Untuk mendapatkan hasil yang optimal, maka akan dilakukan tindakan siklus II yang bertolak ukur pada hasil pengamatan pada siklus I. Untuk menunjang ketercapaian pada siklus II, maka dilakukan perevisian materi kegiatan pada siklus I untuk dijadikan sebagai bahan perencanaan penyusunan materi kegiatan pada siklus II.

Berasarkan hasil pengamatan yang dilakukan di Siklus II dari 10 anak di PAUD (Kelompok Bermain) Bintang Kecil yang telah Berkembang sesuai harapan ada 4 orang anak yaitu AW, AA, NA, dan NZ, dan yang dalam tahap Berkembang ada 4 orang anak yaitu AN, MNA, QF dan FBA. Dan yang Mulai Berkembang ada 2 orang yaitu ANH, dan FAR,. Sehingga perkembangan kemampuan motorik halus anak yang terjadi pada siklus II ini mencapai $40 \%$ sehingga belum 


\section{"Ceria"}

Jurnal Pendidikan Anak Usia Dini

ISSN 2301-9905

Volume 10, No. 1, Juli 2019

Fakultas Keguruan dan Ilmu Pendidikan- Universitas Muhammadiyah Tangerang

mencapai indikator keberhasilan dalam penelitian ini, maka perlu dilakukan siklus berikutnya yaitu siklus III.

Selanjutnya peneliti melakukan perbandingan perkembangan kemampuan motorik anak pada siklus I dengan siklus II. Hasil dari pengamatan tersebut memperlihatkan adanya perubahan kemampuan motorik anak yang cenderung meningkat pada siklus II. Setelah pelaksanaan pembelajaran pada siklus II selesai dilakukan refleksi. Melalui aspek pada perkembangan kemampuan motorik halus anak diketahui 50\% sudah menunjukkan kategori Berkembang Sesuai Harapan (BSH), sehingga perlu dilakukan siklus III.

Berasarkan hasil pengamatan yang dilakukan di Siklus III dari 10 anak di PAUD (Kelompok Bermain) Bintang Kecil yang telah Berkembang sesuai harapan ada 8 orang anak yaitu AW, AA, AN, FBA, MNA, NA, NZ dan QF. Dan yang Mulai Berkembang ada 2 orang yaitu ANH dan FAR,. Sehingga perkembangan kemampuan motorik halus anak yang terjadi pada siklus III ini mencapai $80 \%$ sehingga telah mencapai indikator keberhasilan dalam penelitian ini.

Peneliti melakukan perbandingan perkembangan kemampuan motorik anak pada siklus II dengan siklus III. Hasil dari pengamatan tersebut memperlihatkan adanya perubahan kemampuan motorik anak yang cenderung meningkat pada siklus III. Setelah pelaksanaan pembelajaran pada siklus III selesai dilakukan refleksi. Melalui aspek pada perkembangan kemampuan motorik halus anak diketahui 80 \% sudah menunjukkan kategori Berkembang dengan Baik ( BB).

Dengan demikian hipotesis tindakan yang berbunyi melalui model pembelajaran sentra alam dapat meningkatkan kemampuan motorik halus anak di PAUD (Kelompok Bermain) Bintang Kecil Karawaci Kota Tangerang dapat diterima kebenarannya, sehingga tidak perlu dilakukan siklus selanjutnya. 
Jurnal Pendidikan Anak Usia Dini

ISSN 2301-9905

Volume 10, No. 1, Juli 2019

Fakultas Keguruan dan Ilmu Pendidikan- Universitas Muhammadiyah Tangerang

\section{Kesimpulan}

Berdasarkan hasil penelitian yang telah dilaksanakan maka dapat ditarik kesimpulan bahwa melalui model pembelajaran sentra alam dapat meningkatkan kemampuan motorik halus anak usia 4-5 tahun di PAUD (Kelompok Bermain) Bintang Kecil Karawaci Kota Tangerang. Hal tersebut ditandai adanya peningkatan kemampuan motorik halus anak dimana pada siklus I sebesar $20 \%$, dari 10 siswa, pada siklus II sebesar $40 \%$ dari 10 siswa, dan pada siklus III $80 \%$ dari siswa. Sehingga prosentase kenaikan dari siklus I ke siklus II adalah sebesar $20 \%$ dan prosentase kenaikan dari siklus II ke siklus III adadlah $40 \%$.

Terbukti dari hipotesis tindakan menunjukkan bahwa apabila guru Pendidikan Anak Usia Dini (Kelompok Bermain) menggunakan model pembelajaran sentra alam dalam proses pembelajaran maka kemampuan motorik halus pada anak usia 4-5 tahun akan meningkat.

Media pembelajaran perlu disiapkan dengan baik agar menumbuhkan minat anak untuk melaksanakan kegiatan. Dalam proses kegiatan pembelajaran guru harus memberikan kesempatan bagi anak untuk berekspresi mengembangkan gagasan dan perasaannya baik secara lisan maupun tertulis dalam karya - karya anak.

\section{Daftar Acuan}

Agustya. 2014. Pengenalan Pembelajaran Sentra Pada Anak Usia Dini. Jakarta : Global.

Ahmad Sudrajat. 2008. Pembelajaran Kontekstual. CV. Daimon.

Asholihin.2013. Anak Bermain Belajar, http://paud-anakbermainbelajar.blogspot.com/2013/06/carlangkah- langkahpelaksanaan-bcct.html) 


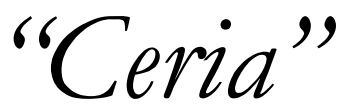

Jurnal Pendidikan Anak Usia Dini

ISSN 2301-9905

Volume 10, No. 1, Juli 2019

Fakultas Keguruan dan Ilmu Pendidikan- Universitas Muhammadiyah Tangerang

Bambang, Sujiono. 2005. Metode Pengembangan Fisik. Jakarta : Penerbit Universitas Terbuka. Cipta Karya

Emzir. 2010. Metodologi Penelitian Kualitatif: Analisis Data. Jakarta: Raja Grafindo

Endang Rini Sukamti. 2010. Peningkatan Perkembangan Motorik Halus Anak. Yogyakarta : UNY

Gumilar, Ismail. 2013. Sentra Pendidikan Anak Usia Dini. Jakarta : Person Press.

Hamruni. 2009. Edutainment dalam Pendidikan Islam dan Teori - Teori Pembelajaran Quantum. Yogyakarta : UIN Sunan Kalijaga.

Harianti, Diah. 1995. Program Kegiatan Belajar Taman Kanak-Kanak. Jakarta : Multi Crop

Hurlock E.B. 1978. Chiled Development. $6^{\text {th }}$ Ed. Tokyo : Mc. Graw Hill.Inc,

Hurlock E.B. 1998. Perkembangan Anak. Jakarta : Erlangga. International Student.Ed

Kartini, Kartono. 1995. Perkembangan Motorik pada Anak Usia Dini. Yogyakarta : Perdana Press.

Killen Roy. 1989. Effective teaching Strategies. Lesson from Research and Practse, Second Edition, Australia : Social Science Press.

Latif, Mukhrat. 2013, Pengembangan Pembelajaran Sentra, Bandung : Kencana Press.

Rachmad Widodo. 2009. Menciptakan Pembelajaran Aktif Kreatif pada Anak. Jakarta : Surya Media Press.

Ratna, Pangastuti, 2014. Edutaintment Pendidikan Anak Usia Dini. Yogyakarta : Pustaka Pelajar.

Retno. 2010. Panduan Pendidikan Sentra Untuk Pendidikan Anak Usia Dini. Jakarta : Pustaka Al-Falah

Rina Kusumawati. 2013. Metode Pembelajaran Sentra. Jakarta : Pustaka Setia. 


\section{"Ceria"}

Jurnal Pendidikan Anak Usia Dini

ISSN 2301-9905

Volume 10, No. 1, Juli 2019

Fakultas Keguruan dan Ilmu Pendidikan- Universitas Muhammadiyah Tangerang

Sanjaya, Wina. 2006. Strategi Pembelajaran Berorientasi Standar Proses Pendidikan. Jakarta : Prenada Media Group.

Sujiono. 2009. Pembelajaran Sentra. Yogyakarta : Candra Press.

Sumantri. 2005. Konsep Dasar Pendidikan Anak Usia Dini. Jakarta : PT. Indeks.

Tim Pengembang. 2008. Pengembangan Model Pembelajaran di Taman Kanak Kanak. Jakarta : Departemen Pendidikan Nasional

Tim Penyususn Naskah PLPG PAUD - FIP UNJ. 2012. Modul Pendidikan dan Pelatihan Profesi Guru Taman Kanak - Kanak. Jakarta : Copyright.

Trianto. 2011. Model - Model Pendidikan Anak Usia Dini, Jakarta : Ghiyats Alfiani Press.

Udin, Winataputra, 1994. Model Pembelajaran. Bandung : Sless Press

Woolfson. 2001. Bayi yang Cerdas, Memahami dan Merangsang Perkembangan Anak Anda. Batam Centre : Karisma Publishing Group

Yudha. Rudhianto. 2005. Perkembangan anak Usia Dini. Bandung : Cahaya Group. 